\title{
Preventive Efforts On Criminal Violence Of Women
}

\section{Mohamad Sugiyarto*) and Umar Ma'ruf**)}

*) Student of Master of Law, Faculty of Law, Universitas Islam Sultan Agung (UNISSULA), Village Officials in Karaban Village, Gabus District, Pati Regency Jl. Pati-Kayen, email: giarto0704@gmail.com

**) Faculty of Law Universitas Islam Sultan Agung

\begin{abstract}
The objectives of this study were (1) to find out and analyze why there was a criminal act of violence against women in Pati Regency, (2) To identify and analyze efforts to overcome criminal acts of violence against women in Pati Regency, (3) To identify and analyze the obstacles what are the obstacles) in law enforcement for criminal acts of violence against women in Pati District and what are the solutions. The method used in this research is empirical juridical research. Sources and data types use primary data and secondary data. The data collection process was carried out by observing techniques, interviews, documentation, and literature, while the analysis method used was qualitative analysis. The research problem is analyzed by using Human Rights Theory and Law Enforcement Theory.In the effort to overcome and prevent perpetrators of domestic violence, it must be supported by increasing legal awareness of the community. Public legal awareness is a part of legal culture. This is said to be one part, because so far there is a perception that the legal culture only includes the legal awareness of the community. In essence, there are several approaches that can be taken to deal with domestic violence, namely through a preventive approach, a curative approach and a medical approach.
\end{abstract}

Keywords: Prevention; Crime; Women; Violence.

\section{Introduction}

Violence against women today is not only an individual problem, but also a national problem and is even a global problem. Indonesia as a developing country has a bad reputation in the problem of human rights violations, one of which is a violation of women's human rights. Serious human rights violations against women can be classified as acts of violence against women. ${ }^{1}$ Basically, gender violence is caused by the inequality of power that exists in society. ${ }^{2}$

In the Criminal Code there are several articles that are directly related and can qualify as acts of physical violence against women, namely, Articles 351 to Article 356 of the Criminal Code. While the victims referred to in the law are people who experience violence or threats of violence in the household sphere, such as husbands, wives, children of people who have family relations with core members (husband, wife, children) due to blood relations, marriage, breastfeeding, orgasm, and guardianship, which settle in the household. ${ }^{3}$

Victim crimebasically it is the party who suffers the most as a result of the crime, apparently not getting that much protection provided by the law to the perpetrators of the crime. As a result, when the perpetrator's file has been convicted by a criminal sanction court, the victim of the crime is completely

1 Fathul Jannah, 2002, Kekerasan Terhadap Istri, LKIS, Yogyakarta, p. 1.

2 Mansour Fakih, 2012, Analisis Gender dan Transformasi Sosial, Pustaka Pelajar, Yogyakarta, p. 16.

3 Act No. 23 of 2004 concerning the Elimination of Domestic Violence 
neglected. In fact, the issue of justice and respect for human rights does not only apply to offenders but also to victims of crime. This crime continues to be a major problem and challenge faced by the government and society. ${ }^{4}$

Based on this, the compilers are interested in conducting research with the title, "Efforts to Prevent Criminal Acts of Violence Against Women in Pati Regency".

Based on the background of the problem, the compilers formulated the following issues: (1) Why did violence against women occur in Pati District? (2) How are the efforts to tackle criminal acts of violence against women in Pati District? (3) What are the obstacles in law enforcement for criminal acts of violence against women in Pati District and what are the solutions?

\section{Research Methods}

In analyzing the data, researchers used qualitative analysis techniques ${ }^{5}$ namely by analyzing the data that has been collected from various sources then dividing it into facts and opinions to get answers to the problems and then conclusions are drawn using an Empirical Juridical approach. The data collection process was carried out by observing techniques, interviews, documentation, and literature.This study uses two data sources, namely primary data and secondary data. ${ }^{6}$

\section{Result And Discussion}

\subsection{Causes of Criminal Acts of Violence Against Women in Pati District}

A happy family life is certainly the dream of every married couple, but often things cannot go as expected, small problems in marriage are normal, but what is unfortunate is when the small problems that color the household dip are tainted with unpleasant actions or disadvantage one of the parties, namely the occurrence of Domestic Violence (DV).

Based on the results of interviews with informants, in general the causes of violence against women in Pati District include:

a. The helplessness of victims of violence

The helplessness of victims of violence in this case is related to future economic fulfillment, both for themselves and for their children. And The assumption that the wife belongs to the husband and that a husband has higher power than other family members makes men more likely to commit violence. ${ }^{7}$

b. Level of education

\footnotetext{
4 Roswati Dewi, Sri Endah Wahyuningsih and Umar Ma'ruf, 2019, Law Enforcement Of Giving Restitution For Victims Of Trafficking In The State Court Of Central Jakarta, dalam Jurnal Daulat Hukum Volume 2 Issue 4, published Master of Law, Faculty of Law UNISSULA, p. 540, http://jurnal.unissula.ac.id/index.php/RH/article/view/8363/3896

5 Tohirin, 2012, Metode Penelitian Kualitatif Dalam Pendidikan Dan Bimbingan Konseling, Rajawali Pers, Jakarta, p. 142.

6 Husein Umar. 2013. Metode Penelitian untuk Skripsi dan Tesis, Rajawali, Jakarta, p. 42.

7 Muchsin, "Peranan Putusan Hakim pada Kekerasan dalam Rumah Tangga", in Varia Peradilan Law Magazine of XXII No. 260 July 2007, p. 23
} 
Although the majority of the level of education in Pati Regency is already high, the number of cases of violence that has been successfully resolved is very low. Because many people do not understand about domestic violence, either understanding related to regulations regarding domestic violence or understanding what is meant by domestic violence itself.

c. Domestic Violence Is a Family Disgrace

The high respect for a culture that states domestic violence is a disgrace, gives an impact that domestic violence should not be spread or in other words must be covered up. The act of covering up the violence that befell the victim, according to the author, is very detrimental to the victim. This is because domestic violence is a recurring cycle, ${ }^{8}$ which will not stop if not disconnected.

d. Reluctant to the victim

The majority of victims of domestic violence are women. So that if there is domestic violence with the perpetrator of the husband, the victim will feel sorry if her husband is convicted, especially imprisonment even though the husband has actually committed violence against him.

e. Expectations of Domestic Violence Perpetrators Heal

The wife as a victim of domestic violence has the hope that the perpetrator of violence will recover (will not repeat the action) by itself. So that wives who experience domestic violence will tend to apologize to the perpetrators.

f. Affair

One of the causes of the division in the married life of a husband and wife is that there is an affair committed by one party or both partners, so that a dispute will occur.

The impacts of domestic violence include:

a. Physical impacts, such as traces of violence on the part of the victim's body in the form of encouragement, pinching, kicks, beatings with a bat, being showered with chemicals or hot water, drowning and gunfire. ${ }^{9}$

b. Non-physical (psychic) impact, a form of violence that attacks or is aimed at someone's psychic (mental or psychological), either in the form of insults, comments aimed at degrading a person's dignity, prohibitions or threats.10

According to the author, based on the above research, studied with the theory of human rights, then the cause of the crime of violence against women in Pati Regency is where The state of Indonesia is a state based on law as stipulated in the 1945 Constitution Article 1 paragraph (3), namely the State of Indonesia is a state based on law, and in exercising its rights and freedoms, citizens are regulated in Article 28:

a. Everyone is obliged to respect the human rights of others in an orderly life of society, nation and state.

b. In exercising his rights and freedoms, everyone is obliged to comply with the restrictions established by law only for the purpose of guaranteeing recognition

8 Lenore Walker in Mark Cotanzo, 2006, Aplikasi Psikologis dalam Sistem Hukum, Pustaka Pelajar, Yogyakarta, p. 126.

9 Aroma Elmina Martha, 2003, Perempuan Kekerasan dan Hukum, UII Press, Yogyakarta, p. 35.

10 Moerti hadiati Soeroso, S.H., M.H., 2011, Kekerasan Dalam Rumah Tangga Dalam Prespektif Yuridis-Viktimologis, Sinar Grafika, Jakarta, p. 81. 
and respect for the rights and freedoms of others and for fulfilling justice demands in accordance with considerations of moral, religious values, security and public order in a democratic society. 11

Based on the contents of the law above, it can be said that the struggle of women in achieving equality and justice that has been carried out has not been able to raise the dignity of women to be equal with men. Because there are still many women in Pati Regency who do not know the meaning of domestic violence.

Meanwhile, according to the author, studied with Law Enforcement Theory, then the causes of criminal acts of violence against women in Pati Regency according to Soerjono Sukanto are several factors that can influence law enforcement itself, including: (1) The legal factors themselves are limited by law only. (2) Law enforcement factors. (3) Facilities and facilities that support law enforcement. (4) Community factors. (5) Cultural factors.12

Based on the theory above, it is related to the research results, that domestic violence in Pati Regency often occurs because of the many affairs that occur and the village officials are not firm in dealing with the problem.

\subsection{Efforts to Overcome Criminal Violence Against Women in Pati District}

a. Preventive Countermeasures ${ }^{13}$

Namely efforts made early through educational activities. In the interview the researcher with the chairman of BABINSA, mr. Mulyono said that violence in household is a reflection of the worthlessness of women in the eyes of their husbands and an insult to the dignity of women whose rights must be guaranteed. So in this case, law enforcers carry out a socialization about domestic violence so that by providing this socialization the community can find out the extent of domestic violence and how legal sanctions are given to perpetrators of domestic violence in accordance with the article regulating internal violence. the household.

b. Curative Countermeasures

Namely actions taken to deal with victims in an integrated manner. In the interview the researcher with the chairman of BABINSA, mr. Mulyono said, in fact there are many ways that can be done by both parties in domestic violence in order to avoid violence, namely: the existence of faith and piety in individuals, having knowledge that domestic violence will have a negative impact on the household, good communication between husband and wife and mutual trust and respect between family members.

c. Medication Efforts

In an effort to overcome violence in household, the government provides a service for health workers to undergo medical recovery therapy so that victims

11 Ageng Wicaksana and Umar Ma'ruf, 2020, Investigation of the Crime of Embezzlement in Property, in Jurnal Daulat Hukum Volume 3 Issue 3, published Master of Law, Faculty of Law UNISSULA, p. 338. http://dx.doi.org/10.30659/jdh.v3i3.11246

12 Soerjono Soekanto, 2007, Pokok-pokok Sosiologi Hukum, PT Raja Grafindo Persada, Jakarta, p. 110.

13 Wirjono Prodjodikoro, 2004, Asas-Asas Hukum Pidana di Indonesia, PT. Refika Aditama, Bandung, p. 20. 
can return to their daily activities. The results of the researcher interview with the BABINSA chairman, mr. Mulyono, said that efforts to overcome domestic violence, especially in its implementation, are good participation, assistance and cooperation from the wider community.

According to author From the results of the above research studied with the theory of Human Rights the efforts to combat criminal acts of violence against women in Pati District based on the Platform for Action produced by the Fourth World Conference on Women in Beijing in 1995, stated:

"Violence against women is a manifestation of the existence of differences in power in the relations between men and women throughout history, which results in domination and discrimination against women, and this hinders the full progress of women. Violence experienced by women throughout their life basically comes from cultural patterns, especially the damaging effects of certain traditional practices or the harmful habits of all extreme customs related to race, sex, language or religion, which perpetuate their position. less than women in the family, in the workplace, and in society. "

According to the theory of Human Rights studied with the results of the research conducted by the author, then the actions committed by the husband to his wife have violated human rights in general. This is made clear by the statement that the victim has lost her right to protection and justice from BABINSA.

Meanwhile, according to the author, it is studied with Law Enforcement Theory, so in an effort to understand the enforceability or effectiveness of Act No. 23 of 2004 concerning the Elimination of Domestic Violence, the researcher uses the legal enforcement theoretical framework from Soejono Soekanto, where law enforcement will be successful effective if it is supported by factors or characteristics that influence the law. These factors are as follows:

a. The legal factor itself ${ }^{14}$, In general, good legal regulations are legal regulations that are applicable and enforced juridically, sociologically and philosophically.

b. Law enforcement factors, Law enforcers are the parties who form or implement the law.15

c. Facility and facilities factors that support law enforcement. To support good law enforcement, good facilities and facilities are also needed for law enforcement officers.

d. Community factors. What is important is the legal awareness of the community, the higher the legal awareness of the community, the better the law enforcement, conversely, the lower the level of public legal awareness, the more difficult it is to implement good law enforcement.16

e. Cultural factors. Cultural factors basically include the values that underlie the applicable law, which values are abstract conceptions of what is considered good and what is considered bad.17

14 Sugandhi, 1980, KUHP Dengan Penjelasannya, Usaha Nasional, Surabaya, p. 314.

15 Soerjono Soekanto, 2004, Faktor-Faktor Yang Mempengaruhi Penegakan Hukum, ed. 5, Raja Grafindo Persada, p. 5.

16 Farhana, 2010, Aspek Hukum PerdaganganOrang di Indonesia, Sinar Grafika, Jakarta, p. 68.

17 Anggraeni Noer Septaningrum, Penegakan Hukum Tindak Pidana Trafficking (Studi Putusan Pengadilan Negeri Yogyakarta), Skripsi, (Yogyakarta: Sharia and Law, UIN Sunan Kalijaga University), p. 14. 
From the above statement regarding the theory of law enforcement related to the results of research that, violence against women in Pati District, the author tries to socialize to $R T$ heads, $P K K$ mothers, village cadres, village government so that acts of violence against women can be reduced.

\subsection{Obstacles in Law Enforcement of Criminal Acts of Violence Against Women in Karaban Village, Gabus District, Pati Regency and The Solutions}

From the results of the research conducted by the author, it is found that there are obstacles in law enforcement for criminal acts of violence against women, including: the strong dependence of wives on their husbands. The problem that has often arisen in handling Domestic Violence is that the victim only wants to deter her husband from his actions and by getting a warning from law enforcers for his behavior.

With the rise in cases of domestic violence (DV) that often occur, it is necessary to have the right solution to minimize cases of domestic violence, namely:

a. Curative function. This action is intended to provide awareness to perpetrators of domestic violence so that they can realize their mistakes and be able to improve their next life, so that in the future they are expected not to repeat their actions again.

b. Remedial or rehabilitative function, this function focuses on healing the client's psychological problems, restoring mental health and overcoming emotional disorders.

According to the author, studied with the theory of human rights, the obstacles (barriers) in law enforcement for criminal acts of violence against women in Pati Regency and their solutions. That the desire to resolve cases of domestic violence as mandated by Act No. 23 of 2004 concerning the Elimination of Domestic Violence is a common hope / ideal for all elements in this country, especially competent parties. either from the Police (BABINSA) or the local government and the community in Pati Regency.

The obstacles faced by competent parties in the context of resolving domestic violence cases in Pati Regency are that apart from being closely related to the legal formulation (substance) it is also inseparable with the problem of violence and the problem of men who often migrate.

Meanwhile, according to the author, it is studied with law enforcement theory, the obstacles in law enforcement for criminal acts of violence against women in Pati Regency and their solutions. Domestic violence is a social problem, not a family problem that needs to be hidden. This is stated in the rules listed in Article 11 of Act No. 23 of 2004 which reads: "The government is responsible for efforts to prevent domestic violence."

Based on the theory above, the authors found obstacles to violence against women in Pati Regency, namely government officials who were less proactive in responding to domestic violence problems that occurred in the community, the victim was afraid that his name would become bad, and feared that it would break the law. To overcome these obstacles, the government must be proactive towards 
acts of domestic violence, the government must also provide education to the public about acts of violence and their impacts so that acts of violence against women can be reduced.

\section{Closing}

Efforts to tackle and prevent perpetrators of domestic violence must be supported by increasing legal awareness of the community. Public legal awareness is a part of legal culture. This is said to be one part, because so far there is a perception that the legal culture only includes the legal awareness of the community. In essence, there are several approaches that can be taken to deal with domestic violence, namely through a preventive approach, a curative approach and a medical approach.

Based on conclusion The results of the research can be put forward several suggestions, including: there must be good communication between husband and wife and victims of domestic violence should not hesitate to share problems with their families.

\section{References}

\section{Books:}

[1] Anggraeni Noer Septaningrum, Penegakan Hukum Tindak Pidana Trafficking (Studi Putusan Pengadilan Negeri Yogyakarta), Skripsi, (Yogyakarta: Sharia and Law, UIN Sunan Kalijaga University)

[2] Aroma Elmina Martha, 2003, Perempuan Kekerasan dan Hukum, UII Press, Yogyakarta

[3] Farhana, 2010, Aspek Hukum PerdaganganOrang di Indonesia, Sinar Grafika, Jakarta

[4] Fathul Jannah, 2002, Kekerasan Terhadap Istri, LKIS, Yogyakarta

[5] Husein Umar. 2013. Metode Penelitian untuk Skripsi dan Tesis, Rajawali, Jakarta

[6] Lenore Walker in Mark Cotanzo, 2006, Aplikasi Psikologis dalam Sistem Hukum, Pustaka Pelajar, Yogyakarta

[7] Mansour Fakih, 2012, Analisis Gender dan Transformasi Sosial, Pustaka Pelajar, Yogyakarta

[8] Moerti hadiati Soeroso, S.H., M.H., 2011, Kekerasan Dalam Rumah Tangga Dalam Prespektif Yuridis-Viktimologis, Sinar Grafika, Jakarta

[9] Muchsin, "Peranan Putusan Hakim pada Kekerasan dalam Rumah Tangga", in Varia Peradilan Law Magazine of XXII No. 260 July 2007

[10] Soerjono Soekanto, 2004, Faktor-Faktor Yang Mempengaruhi Penegakan Hukum, ed. 5, Raja Grafindo Persada

[11] Soerjono Soekanto, 2007, Pokok-pokok Sosiologi Hukum, PT Raja Grafindo Persada, Jakarta

[12] Sugandhi, 1980, KUHP Dengan Penjelasannya, Usaha Nasional, Surabaya

[13] Tohirin, 2012, Metode Penelitian Kualitatif Dalam Pendidikan Dan Bimbingan Konseling, Rajawali Pers, Jakarta 
[14] Wirjono Prodjodikoro, 2004, Asas-Asas Hukum Pidana di Indonesia, PT. Refika Aditama, Bandung

\section{Journals:}

[1] Ageng Wicaksana and Umar Ma'ruf, 2020, Investigation of the Crime of Embezzlement in Property, in Jurnal Daulat Hukum Volume 3 Issue 3, published Master of Law, Faculty of Law UNISSULA, p. 338. http://dx.doi.org/10.30659/jdh.v3i3.11246

[2] Roswati Dewi, Sri Endah Wahyuningsih and Umar Ma'ruf, 2019, Law Enforcement Of Giving Restitution For Victims Of Trafficking In The State Court of Central Jakarta, dalam Jurnal Daulat Hukum Volume 2 Issue 4, published Master of Law, Faculty of Law UNISSULA, p. 540, http://jurnal.unissula.ac.id/index.php/RH/article/view/8363/3896

\section{Regulation:}

Act No. 23 of 2004 concerning the Elimination of Domestic Violence 